\title{
Erratum to: Analysis of necroptotic proteins in failing human hearts
}

\author{
Adrián Szobi ${ }^{1}$, Eva Gonçalvesová ${ }^{2}$, Zoltán V. Varga ${ }^{3}$, Przemyslaw Leszek ${ }^{4}$, Mariusz Kuśmierczyk ${ }^{4}$, \\ Michal Hulman ${ }^{5}$, Ján Kyselovič ${ }^{1}$, Péter Ferdinandy ${ }^{3}$ and Adriana Adameová ${ }^{*}$
}

\section{Erratum to: J Transl Med (2017) 15:86 DOI 10.1186/s12967-017-1189-5}

In the original version of this article [1], published on 28 April 2017, the name of author 'Zoltán V. Varga' was wrongly displayed.

Originally the author name has been published as:

- Zoltán Varga

The correct author name is:

- Zoltán V. Varga

The original publication of this article has been corrected.
The online version of the original article can be found under doi:10.1186/s12967-017-1189-5.

\section{Publisher's Note}

Springer Nature remains neutral with regard to jurisdictional claims in published maps and institutional affiliations.

Published online: 11 May 2017

\section{Reference}

1. Szobi A, Gonçalvesová E, Varga ZV, Leszek P, Kuśmierczyk M, Hulman M, Kyselovič J, Ferdinandy P, Adameová A. Analysis of necroptotic proteins in failing human hearts. J TransI Med. 2017;15:86. doi:10.1186/ s12967-017-1189-5.

\section{Author details}

${ }^{1}$ Department of Pharmacology \& Toxicology, Faculty of Pharmacy, Comenius University in Bratislava, Odbojárov 10, 83232 Bratislava, Slovakia. ${ }^{2}$ Department of Heart Failure \& Transplantation, The National Institute of Cardiovascular Diseases, Bratislava, Slovakia. ${ }^{3}$ Department of Pharmacology \& Pharmacotherapy, Semmelweis University, Budapest, Hungary. ${ }^{4}$ Institute of Cardiology, Warsaw, Poland. ${ }^{5}$ Clinic of Heart Surgery, The National Institute of Cardiovascular Diseases, Bratislava, Slovakia.

\footnotetext{
*Correspondence: adameova@fpharm.uniba.sk

1 Department of Pharmacology \& Toxicology, Faculty of Pharmacy, Comenius University in Bratislava, Odbojárov 10, 83232 Bratislava, Slovakia

Full list of author information is available at the end of the article
} 